\title{
The taking of Western/Euro Mathematics as reappropriation/repair
}

\author{
Peter Appelbaum \\ Charoula Stathopoulou
}

\begin{abstract}
Reorienting ethnomathematics away from reclaiming or celebrating epistemologies lost to colonialization, we propose the need to position local knowledges ${ }^{1}$ as the authorities that re appropriate Western Mathematical traditions in the service of local cultures and concerns. Drawing from several postcolonial novels in which a divided world and clash of traditions is at the center of character, plot, politics, and the human condition (Jhumpa Lahiri's The Namesake, Nuruddin Farah's North of Dawn) applying the work of Ligia (Lichio) Lopez, on the construction of indigeneity as a form of coloniality, we urge the application of a metaphor in order to understand and interpret mathematics education through the prism of ethnomathematics. Can one enjoy the privileges of western civilization and yet perceive resistance in this acculturation process as a positive action of affirmation? What are the corresponding costs for any choice? What about students - mostly out of mainstream - at school that very often are confronting a similar dilemma?
\end{abstract}

Keywords: Ethnomathematics. Coloniality. Mathematics Education. Post-Colonial. Reappropriation/Repair.

\section{La toma de las Matemáticas Euro/Occidentales como reapropiación/reparación}

Resumen: Reorientando las Etnomatemáticas, lejos de recuperar o celebrar las epistemologías perdidas por la colonización, proponemos la necesidad de posicionar el conocimiento local como las autoridades que reorientan las tradiciones matemáticas occidentales al servicio de las culturas y preocupaciones locales.

Peter Appelbaum Ph.D. in Educational Foundations, POlicy and Administration from teh University of Michigan, Ann Arbor, Professor of Mathematics Education and Education Studies at Arcadia University, Philadelphia, USA Director of Education Studies and Art Education Programs, Arcadia University, Philadelphia, USA

iD https://orcid.org/0000-0002-6011-6342 $\bowtie$ appelbap@arcadia.edu

Charoula Stathopoulou Ph.D. in Ethnomathematics at the University of the Aegean, Greece Professor of Mathematics and the Didactics of Mathematics in the Department of Special Education at the University of Thessaly, Greece. Principal Coordinator of the European Union CoSpIRom Common Spaces for the Integration of Roma Project.

iD https://orcid.org/0000-0001-9277-1010

$\bowtie$ hastath@uth.gr

Received in 09/09/2019 Accepted in 14/12/2019 Published in 04/03/2020
Basado en varias novelas poscoloniales en las que un mundo dividido y un conflicto de tradiciones están en el corazón del carácter, la trama, la política y la condición humana (El homónimo escrito por Jhumpa Lahiri, El amanecer del norte escrito por Nuruddin Farah) y al aplicar el trabajo de Ligia (Lichio) López en la construcción de la indigeneidad como una forma de colonialidad, instamos al uso de una metáfora para comprender e interpretar la educación matemática a través del prisma de la Etnomatemática. ¿Alguien puede disfrutar de los privilegios de la civilización occidental y aún percibir la resistencia en este proceso de aculturación como una acción de afirmación positiva? ¿Cuáles son los costos correspondientes para cualquier elección? ¿Qué pasa con los estudiantes - especialmente fuera del sistema convencional - en la escuela que a menudo enfrentan un dilema similar?

Palabras clave: Etnomatemáticas. Colonialidad. Educación Matemática. Poscolonial. Reapropiación/Reparación.

\section{A Tomada da Matemática Euro/Ocidental como reapropriação/reparo}

Resumo: Reorientando a Etnomatemática, longe de recuperar ou celebrar epistemologias perdidas pela colonização, propomos a necessidade de

\footnotetext{
1 With the term local knowledge, we mean knowledge that emerges and develops in communities through members experience, addressing their needs and problems. This knowledge is often underestimated by others, and exists outside of the Western knowledge corpus. Every community develops such knowledge; in the context of literacy what is commonly described as local knowledge or indigenous knowledge might be better grasped as local knowledge.
} 
posicionar os conhecimentos locais como as autoridades que reorientam as tradições matemáticas ocidentais a serviço das culturas e das preocupações locais. Com base em vários romances pós-coloniais, nos quais um mundo dividido e um conflito de tradições estão no centro do personagem, da trama, da política e da condição humana (O Xará escrito Jhumpa Lahiri, O Norte do Amanhecer escrito por Nuruddin Farah) e, aplicando a obra de Ligia (Lichio) Lopez, na construção da indigeneidade como uma forma de colonialidade, instigamos a utilização de uma metáfora para entender e interpretar a educação matemática por meio do prisma da Etnomatemática. Alguém pode usufruir os privilégios da civilização ocidental e ainda assim perceber a resistência nesse processo de aculturação como uma ação positiva de afirmação? Quais são os custos correspondentes para qualquer escolha? E os alunos - principalmente fora do sistema convencional - na escola que, muitas vezes, enfrentam um dilema semelhante?

Palavras-chave: Etnomatemática. Colonialidade. Educação Matemática. Pós-colonial. Reapropriação/Reparo.

If we cannot understand why a mathematics classroom falls apart, then neither can we understand why mathematics education does

\section{A kind of introduction}

Ethnomathematics emerged as a way to repair the consequences of colonization; to respond to education's - and especially Mathematics Education's - problems for oppressed people in Latin America, Africa, and other colonies or former colonies (KHAN, 2011). The legacies of colonization include a binary division of people into two main categories: colonizers and colonized, or in other words, a hierarchy of settlers and those who are subject to the exercise of settler power. Colonization belongs in many locations to the past.

However, structures of inequity and hierarchy that preserve forms of power and authority permeate culture, politics, economics, and geopolitical responses to global affairs; these perpetuating structures and their impact at every micro and macro level of everyday life and politics collectively make up what is often called 'coloniality'. For example, Apartheid is no longer an official policy in South Africa, yet segregated communities remain, and life opportunities continue to be highly stratified. Educational systems around the world continue to strive for accreditation by agencies such as the International Baccalaureate, or to be proud of their performance on PISA or TIMSS tests, designed by institutions that owe their heritage and values to former colonizing countries, and who owe their authority to the colonial past.

Developing nations conform to the demands of economic and geopolitical structures in order to benefit from loans and programs sponsored by the Western IMF and the World Bank. Migrants, refugees and Roma, for example, continue to experience coloniality in several dimensions of their lives, including education, a loss of home life autonomy, required adjustment of desires to the whims of authorities, and so on. 
In this article we disrupt the hierarchies of coloniality. We position local knowledges as the authorities that re-appropriate Western Mathematical traditions in the service of local cultures and concerns. This is a somewhat radical endeavor, since the historical context is the ongoing suppression or total erasure of local knowledges, and the totalizing expectation that the colonized learn and assimilate the epistemologies, knowledges, and associated ignorances of the colonizers; Gerdes (2004) speaks about frozen knowledge, the knowledge of former colonized people that was oppressed or lost.

Colonization and Coloniality construct a hierarchy of knowledges and practice that privilege Western European modes as superior, often going so far as to obliterate the existence of available alternatives. In order to function in society and to find a means of basic survival and subsistence, subjects of colonization and now of coloniality have needed to cross boundaries of culture, knowledge, and modes of thinking, and 'live' in the world views and epistemologies of the colonizers, either by force or simple survival strategy.

Early Ethnomathematics emerged in this context, serving two primary functions: as recognition of the situation; and as a resource for perpetuating coloniality. In the first of these roles, ethnomathematics provided a perspective that explained why colonized populations might struggle with school mathematics. In this role, ethnomathematics offered forms of local culture that shared properties with the mathematical concepts and skills that were transported from Western European curricula into local lives in and out of school.

Ethnomathematics also offered a colonization perspective on colonized cultures that could be exploited in Western European school programs: examples of traditionally taught mathematics found in indigenous practices around the world, used in Western school curricula, coopted mathematics in this way as a tool of coloniality; that is, the use of non-European examples in the teaching of mathematics as practiced in many schools today is an example of a structure of coloniality, just as the teaching of traditional, Western mathematics around the world, taken as 'the universal definition of mathematics' for all, is itself a structure of coloniality.

The identification of a local traditional as just as much mathematics as Western European mathematics' is the ultimate example of coloniality: something is recognized and legitimized as mathematics if and only if it looks like what the colonizing culture sees as mathematics. Entire realms of mathematical activity are in this way reduced to those attributes that conform to the colonizing epistemological structures, and others are forever lost to humanity. Paulus Gerdes (1994) reflected on the early history of ethnomathematics in a similar way, noting that the late 1970 s and early 1980s witnessed a growing awareness among mathematicians of the societal and cultural 
aspects of mathematics and mathematics education; he credits Ubiratan D'Ambrosio for proposing an ethnomathematical program as a methodology to track and analyze the processes of generation, transmission, diffusion, and institutionalization of (mathematical) knowledge in diverse cultural systems.

We ask, what if the response is not to center activity in the discourses and practices of coloniality, but in the centuries-long local traditions and practices that existed prior to colonization, and that have continued to grow and emerge alongside colonization and coloniality? Just as colonizers can be said to have 'raped' and exploited the natural resources and human labor of the colonized, so have the colonized always found ways to exploit and appropriate the tools of the oppressors for their own needs. There are limitations to this way of living coloniality; in the words of Audre Lorde, "the master's tools will never dismantle the master's house" (LORDE, 1979),

Nevertheless, the goal is not so much to dismantle the master's house, but to live as one wishes and to flourish as one dreams, independent of that stranger's craziness; and the local knowledges as the authorities bring more than the 'master's tools' to the project - they bring the rich practices and traditions of local culture, and a curiosity to appropriate and blend ways of thinking and being from all over the world if they are relevant to the task at hand.

Flipping the hierarchy only to preserve the centrality of the colonial culture misses the point, so to speak. Lorde does offer a relevant caveat, nevertheless: this 'radical' adjustment will be threatening to those who see the structures of coloniality as their only means of support: those who benefit from coloniality include the progeny of the colonizers, and also those who might otherwise be labeled as a subject of coloniality who find relative prosperity in the service of colonial structures (this is likely to include teachers, and especially mathematics teachers, who have earned a privileged position within one of the most preeminent institutions of coloniality, schools).

Note that the concept of indigeneity itself is a tool of coloniality, as it differentiates a binary inherent to the colonial project: those who are indigenous and those who are not. In educational situations, the indigenous might be a resource, or the focus of 'problems' with which 'they' are associated, remedied by institutions of coloniality. In this article, we apply the work of Ligia López López on the construction of indigeneity in this way. In particular, we note that educational policies and initiatives targeting mathematics for indigenous populations or celebrating indigenous cultures are often efforts to build a trained workforce for a global economy, one more version of serving institutions of coloniality. Within such initiatives, individuals might find strategies that lead to personal satisfaction and professional opportunities; but the larger context of coloniality and embedded forms of oppression remain intact. In the process, groups of people as well as individuals 
are sorted, ordered and exploited; refusing to be made into kinds of 'indigenous people' with associated problems of coloniality is one form of the shift we are advocating in this work.

There is no traditional methods section in this article, because our scholarship is theoretical and philosophical, not empirical. For understanding and interpreting mathematics education as an acculturation process - mostly for non-mainstream students - through an ethnomathematics perspective, we exploit metaphors inspired by post-colonial novels in which a divided world and the clash of traditions appear as obstacles to a world of living together. Such novels benefit from centuries of inter-cultural and diaspora cultural experience that might inform the work we envision.

They take advantage of literary and historical perspectives on colonization and postcoloniality that include, for example, Edward Said's studies of the ways that colonizers exoticize and romanticize 'others' in Orientalism; Franz Fanon's unraveling of the psychology violence upon colonial subjects leading to the necessity of further violence as the only recourse for undoing such violence, in Wretched of the Earth (FANON, 1961) and Black Skin, White Masks (FANON, 1967); Chinua Achebe's (1958) excruciating depiction of the 'lessons' of colonialism in destroying the known world, in Things Fall Apart; and Aimé Césaire's (1972) creolized intercultural poems that analyze the 'invention of souls'. The current historical moment is flourishing with post-colonial literature, an untapped resource for mathematics education and ethnomathematics.

Why do we take this approach instead of the more typical field-based collaborations or ethnographic methods common to ethnomathematics and mathematics education? We intentionally refuse these methods partly because of the ways in which such research is itself an institution of coloniality, in creating stories about 'others' that feed the stratification of knowledge within academia and public discourse. We claim with Tuck and Yang (2014) that this work is not a story to pass on, but a contribution to a social movement:

\footnotetext{
Social science often works to collect stories of pain and humiliation in the lives of those being researched for commodification. However, these same stories of pain and humiliation are part of the collective wisdom that often informs the writings of researchers who attempt to position their intellectual work as decolonization. Indeed, to refute the crime, we may need to name it. How do we learn from and respect the wisdom and desires in the stories that we (over) hear, while refusing to portray/betray them to the spectacle of the settler colonial gaze? How do we develop an ethics for research that differentiates between power - which deserves a denuding, indeed petrifying scrutiny - and people? At the same time, as fraught as research is in its complicity with power, it is one of the last places for legitimated inquiry. It is at least still a space that proclaims to care about curiosity. In this essay, we theorize refusal not just as a "no," but as a type of investigation into "what you need to know and what I refuse to write in" ... Therefore, we present a refusal to do research, or a refusal within research, as a way of thinking about humanizing researchers (p. 223).
} 
The works of literature discuss here actively theorize the remnants of domination, the shadows of terrible dances and tragic expressions of grief, bursts of joyous transformation and regrettable action. We do not contribute this as an argument for a better form of research, but rather as another kind of scholarship and intellectually useful activity; to suggest that this is a better form of commodified knowledge would be no better than to offer one more ethnography of an indigenous mathematical intervention.

As Tuck and Yang (2014) articulate, engaging literature (and other arts) as theory "especially decolonial literature and art - intervenes upon modes of theorizing in the social sciences, setting limits to social science research and also making those limits permeable to other forms of inquiry. The relationship between research and art can be one of epistemological respect and reciprocity rather than epistemological assimilation or colonization" (p. 237).

\section{Boundary Crossings}

Mugdi and Gacalo, the Somali couple at the heart of Farah Nuruddin's novel, North of Dawn, seem to be exemplars of post-colonial appropriation. In their roomy Norwegian house, Mugdi putters around translating an obscure Norwegian novel, while his wife, Gacalo, works; they are solvent, secular, well-adapted members of the global Somali diaspora, successfully assimilated into European society. Their Norwegian-raised son, Dhaqaneh, joined a terrorist cell in Oslo before fleeing to Somalia, where he killed himself in an Al Shabaab-sponsored suicide attack near Mogadishu. Mugdi, whom a friend describes as "culturally a Muslim," is disgusted and affronted, wanting nothing to do with his son's memory.

But Gacalo insists that she keep her word to Dhaqaneh and care for his wife and stepchildren, currently living in a Kenyan refugee camp. Arriving via a complicated smuggler's route to Europe, Waliya and her children are able to take advantage of Norway's immigrant settlement system and her in-law's sponsorship. But Waliya resists Western practices from the start, even refusing to fasten her seat belt in the car (death would be the will of Allah); when Mugdi shares that he might have to pay a heavy fine to the police if she doesn't, the lines are drawn between fundamentalism and secularism. Shrouded in her black robes, scheming to marry her teenage daughter off to one of the imams, Waliya is an enigma. How could she not want what Mugdi, Norway and the West have to offer: a nice house, a good job, laws that will prevent her from being beaten regularly by a male relative? Our bafflement is complete. 
We offer an analogy between school mathematics and Mugdi's "Giants in the Earth," by Ole Edvart Rolvaag. Rolvaag's saga — published between 1924 and 1925 and the first in a trilogy - concerns a family of Norwegian pioneers in the Dakota Territory of North America, struggling with Native Americans, forces of nature and their immigrant identity. Why is Mugdi translating this work into Somali? Mugdi never asks this. What will Somalians do with this valuable treasure of human culture once it is made accessible to them? Somalia is being reinvented by a new generation, and the audacious, shrouded widow Waliya walks through its ruined streets, dead certain of her place. What did school mathematics or his father's erudite skills with language and translation offer Mugdi's son, now dead at a young age?

The problems of migration, the clashes of fundamentalism and secularism, and other global transnational crises are not necessarily going to be solved by such cultural treasures. Wailya's refusals of Western secularism as solutions to her situation are one version of the inadequacies of coloniality and its structures to anticipate and respond. As a pillar of those structures, school mathematics, like Rolvaag's saga, fails to address the particularities of migration, refugee life, or a post-colonial way forward for humanity.

In The Return, by Dulce Maria Cardoso, 15-year-old Rui is fleeing Angola with his family following the war in Angolan War of Independence; his father is taken away by the rebels as they are on the way to the airport. Not knowing if the father is alive or dead - or if they will ever find out what has become of him, Rui and his mother and sister try to rebuild their lives in their new Portuguese home, a five-star hotel in a quiet, seaside suburb of Lisbon, where returnee families are crammed into luxurious rooms by the dozen. The palatial surroundings are a cruel contrast with the reality of returnee life: The hotel is a nightmarish limbo, as the families wait to discover what will become of them - ever conscious of the fact that they are hardly welcome back in their 'homeland'. As a returnee, Rui curiously represents "Black people," although, as Rui notes, it is a wacky kind of representation ("... here no-one rides trains, the blacks all hang on the wagon doors, but that isn't riding a train.").

Because of Portugal's semi-peripheral condition, that is, its marginal political presence within Europe, the typical binaries of western modernity that undergird so many postcolonial analyses make even less sense than usual when they are used to analyze cultural processes and systems of representation. Santos (2002) offers the concept of "interidentity" to help us understand the specific construction of identities in situations where characteristics pertaining to both colonizer and colonized are combined, as in the 'Portuguese' returnees of this novel. They represent 
themselves to themselves as superior to the black people of Angola, only to experience colonial power dynamics as they flee to the 'homeland.' Back in Angola, Rui recalls,

No-one ever bothered trying to explain who these people are, it was always just the blacks, blacks are lazy, they like to lie in the sun like lizards, blacks are arrogant, if they walk with their heads down it's only so they don't have to look us in the eye, black are stupid, they don't understand what we say to them, blacks are greedy, give them your hand and they'll want the whole arm, blacks are ungrateful, no matter how much we do for them they are never happy, people could talk about blacks for hours but the whites didn't like to waste their time on that, it was enough to say, he's black and we know what that means (CARDOSO, 2016, p. 268).

What happens when those in power become the representation of those in plight? Rui is tossed into Portugal "as if entering the map that hung from the classroom wall" (p. 47) and shares with us,

\begin{abstract}
The staff don't want us here and they don't like serving us. They think the blacks kicked us out of there because we exploited them, we lost everything. It was all our fault and we don't deserve to be here in a five-star hotel being waited on the way we were back there. The staff prefer serving the blacks that can't even hold their cutlery properly to serving us, they think blacks are victims who endured five centuries of oppression and now have had to flee the war (CARDOSO, 2016, p. 962).
\end{abstract}

Here the 'proper use of cutlery' might stand in for school mathematics, and the map on the classroom wall for the application of such culturally-relevant skill sets. The mathematics of school, like the map, is an image of distant yet powerful structures of coloniality, an attribute of an ambiguously useful set of ways to 'fit into' those structures of coloniality, increasingly confusing as to their purpose or need. The anxiety of those in power, that they might lose their privilege and belligerently dream of revenge, is eloquently articulated by our 15 -year-old narrator:

Just let the staff keep feeding those blacks like we did, let them keep serving those blacks and one day they'll see, the blacks rise up in revolt and they do to them what they did to us, they'll bang on their doors and take them away with hands tied behind their backs, they'll take them away and laugh (CARDOSO, 2016, p. 963).

In such a state of fear and fragility, markers of coloniality, such as the map on the classroom wall, the 'proper use of cutlery,' or school mathematics, take on larger-than-life status in pleas for understanding and hopeless efforts at maintaining privilege.

In The Namesake, by Jhumpa Lahiri, a family explores ways to connect traditions from back in India with new cultural expectations in the United States -- as a matter of survival, but also as an attempt to celebrate the mixing of cultures (LAHIRI, 2004). Back in Calcutta, Ashima would have had the baby at home, surrounded by her family; in the United States, the baby and mother survive a hospital delivery, alone, without the family, only to learn that they may not leave the 
hospital without giving their son a legal name - but the traditional naming process is to wait for an elder, who gives the name, and the parents are still waiting for the letter from Ashima's grandmother.

The letter never arrives, and soon after, the grandmother dies. Bengali culture calls for a child to have two names, a 'pet name' used within the family, and a 'good name' to be used in public. Ashoke suggests the name of Gogol, in honor of the famous Russian author, to be the baby's pet name, and they use this name on the birth certificate, because he had been reading a short story by the author as a young man during a train derailment that he luckily survived. Though the pet name has deep significance for the baby's parents, it is never intended to be used by anyone other than family.

Gogol grows up perplexed by his pet name. Entering kindergarten, the Gangulis inform their son that he will be known as Nikhil at school. The five-year-old objects, and school administrators intervene on his behalf, sending him home with a note pinned to his shirt stating that he would be called Gogol at school, as was his preference. By the time he turns 14, he starts to hate the name. His father tries once to explain the significance of it, but he senses that Gogol is not old enough to understand. The name and its changes throughout the plot mirror changing conflicts between Gogol and his parents' relationships to US-American culture, and how they navigate the complexities of hybrid cultural status.

A school project requires Gogol to find a grave at a cemetery: children were to find a grave with their name on it and to depict on their paper the engraved name (all of this was simple for the others, they knew that they were going to be placed in a place like this). But Gogol knew he would burn after his death, and there were no graves with Gogol; he was put in a difficult position. The name in this novel, something so self-evident for the teachers and the school, is symbolic of a host of cultural mismatches, including mathematical knowledge and practices, as well as the consequences of misunderstandings and ignorance.

In some cases, the imbalance of power associated with the mismatches is dramatic and visible. In other situations, it is more like Sara Ahmed's (2006) image of an invisible normative axis: tracing paper. Ahmed proposed a bodily horizon or space for action, which puts some objects in reach and not others. The normative or dominant dimension appears in lines. Things appear straightforward when they line up, as when someone uses thin translucent paper and traces the image beneath. Rather than assuming that the images "line up," we can say that the space for action is readily available when the image does line up. 
When you use tracing paper, the lines disappear when they are aligned with the lines of the images that have been traced, and you simply see one set of lines. If all lines are traces of other lines, then this alignment depends on straightening devices, which keep things in line, in part by holding things in place. Lines disappear through such alignments, so when things come out of line with each other the effect is "wonky." In other words, for things to line up, queer or wonky moments need to be "corrected." Gogol experiences this in terms of his name, or in terms of only half of a pair of names.

\section{Changing the Narratives: Roma Youth in School}

Moving now from fiction to conversations we have had with people in local communities, we note that Roma youth in Greece explain school in several ways that we understand as a straightening device, and school mathematics as a straightening device.

For example, Stelios, a young Roma describes his unfolding experiences of first starting school, and later reflecting on those experiences. He shares: (I did not know) how someone could address the other people (...) what means "hello", what means "how are you", while at the same time the other (non-Roma) children knew from the time they were born what 'hello', 'how are you' mean; How is it, how is the other, they were able to speak comfortably, and they could understand the lessons taught by the teacher. (...) So, lady, when I went to school I thought that the non-Roma people were so different, so important, something that I could never reach. Another young Roma, Christos, expresses his own experience in a related way: I was embarrassed to talk to the other children (he means non-Roma children); I was scared that I would make mistakes (...) after a couple of years had passed, after I (...) it was ok (...) I know now (how to speak Greek) (STATHOPOULOU, 2017).

The above described acculturation process is also depicted in mathematics teaching/learning. In Greek school, Roma students appear to be of low aptitude, and the responsibility for this is placed on the students and not on the school system; students are considered as responsible without consideration of the school as creating conditions of reproducing inequalities. For example, it is easy for someone to realize this just through the space arrangement: usually Roma students are sitting at the far end of the classroom; this segregation is an example of school as an institution of coloniality.

A characteristic case is one of a teacher who said to a prospective teacher visiting his class: in the last desk a Roma boy is sitting; he will not bother you, you will not bother him. Many 
Roma children (fortunately it changes from year to year) stop attending school because of the acculturation process they experience in the classroom, having to follow rules and norms that aren't compatible with their community of origin: they must either adapt to these rules or stop attending school.

The following instance is indicative of the cultural diversity Romany students experience in this context. There were two Romany boys, about ten years old, on their bicycles just outside the schoolyard. After a short discussion, they were asked: why do you not come to school? The two boys pointed to the fenced enclosure with evident ridicule/dismissal/hatred, exclaiming: Don't you see how they are!!!. For them, school is an expression of a lack of freedom, an obvious cultural conflict. The fence was a physical symbol of the broader experience of entering school. This notion of boundaries and enclosures is antithetical to their general life experience, which does not imprison thought or action in enclosures.

Regarding mathematics, Roma appear of low ability according to the demands of school. Teachers typically do not take into consideration who their students are, that is, they do not commonly develop culturally relevant knowledge about their students, nor do they approach their practice in terms of helping children to build understanding on their own everyday knowledge. So, school dictates the rules and according these rules Roma students are constructed as losers. But what if we change the rules, following their experience, bridging this with school instead of creating obstacles? What are the results of Roma and non-Roma students? are they still of lower performance?

We are providing here the case of posing a typical division problem to a Roma students' class with children aged from 7-12 though in first grade and to two typical classes of 4th and 5th grade.

Basilis wants to help his father to distribute apples in crates, which his father has obtained from the vegetable market. In total, the apples weigh $372 \mathrm{~kg}$, and each crate holds $20 \mathrm{~kg}$. How many crates does he need in order to put all the apples in the crates?

Three students invented the same strategy: correspondence of 'one to many;' and in this way, they figured out the correct number of crates. For example Apostolis, one of the students, was drawing lines on his desk: one for each crate (20 kilos).

R: please, tell me Apostolis what are you doing here?

A: 10 crates Miss.

R: How many kilos do the ten crates hold? 
A: $20 \mathrm{~kg}$ every crate.

R: So....

A: Well, 20, 40, (...) 180, 200.

$\mathrm{R}$ : And how many are there?

A: 372

He continued in the same way and found the correct number of crates. Also, he tested the lines he used to correspond each 20 kilos by crossing one-by-one.

The fourth student, Christos, invented a more complex solution. Namely, he used continued subtraction. He was able to subtract, from 372, 20 kilos at a time, and in this way he found the number of needed crates. Such a strategy demonstrates a deep comprehension of the operation of division, managing to conceive it as continued subtraction. Note that these students had being attending school for about 1-2 months, and had not experiences instruction in division nor in the typical algorithm.

The importance of this ability of Roma students became more obvious when this problem was used to test students in typical classes of fourth and fifth grade. None of the fourth grade students managed to find a correct solution using an appropriate algorithm. Some of them selected subtraction: $372-20=352$, or addition: $372+20=392$. These students, although they have found results in such a manner, did not wonder about the viability of their solution. They simply made the right application, without taking into consideration the essence of the problem. Even more interesting was the strategy of two students who used multiplication. They multiplied $20 \times 372$, finding as a result the number: 7.440. These students tested in different ways the result doing the division: $7440 \div 20$. Finding as result 372 , they were confident in their solution. The results of the fifth grade were similar; only one-third of the class managed to solve the problem correctly (STATHOPOULOU, 2005).

Numerous conclusions might be drawn from these stories, and each conclusion might lead to some thoughts about changing school practices. What we can say in general, however, is that enculturation and acculturation processes are taking place in overlapping ways, constraining and enabling, mutually supportive and also in conflict. Some Roma children fundamentally experience school as a cage that directly challenges their humanity.

Although their everyday lives involve shapes, spaces and containers of space, we can only imagine the ways in which the lines of shape and space are 'wonky' in terms of crossing a line of demarcation between the world outside and inside school, interacting with shapes and space in 
geometry lessons, and in trying to understand why very basic everyday knowledge gleaned from working in the market with their families is something alien and needing to be 'explained' or 'examined' in school. What knowledge is most important outside and inside school, and who is supposed to decide this? Such questions have summarily been answered by the institutions of coloniality they experience, yet they also know that the answers are absurd.

\section{Indigeneity: constructions and consequences [for both society and education]}

Drawing from the above extract of the novel where black people are described as "lazy, they like to lie in the sun like lizards, blacks are arrogant, ....) people could talk about blacks for hours but the whites didn't like to waste their time on that, it was enough to say, he's black and we know what that means" and considering these constructions as dangerous for both society and for (mathematics) classrooms, we are exploring: how people - black people, the Indians, Roma, refugee, girls etc. - are still constructed by a dominant western perspective, a Eurocentric perspective in school and outside schools; the implications of these constructions; and we are searching out through ethnomathematics some ways of responding to current problems of humanity that concern the fate of this humanity, as well as how they are depicted directly or indirectly in mathematics classrooms.

Coloniality and challenging coloniality is central to this project. De Santos in his paper, 'Beyond abyssal thinking: From global lines to ecologies of knowledges' (2007) writes about the abyssal gap that separates metropolitan from colonial societies - even today, people who live in or whose origins are in former colonial countries, women, refugees, are considered as inferior. This distinction also concerns people's knowledge, a distinction that is not based on the intrinsic value of various bodies of knowledges, but on the dominant social, political and economic structures. This knowledge is excluded because the people who produce this knowledge are excluded.

'Abyssal thinking consists in granting to modern science the monopoly of the universal distinction between true and false, to the detriment of two alternative bodies of knowledge: philosophy and theology' (p. 50). The result of this assessment of knowledge is to create epistemological clashes between different kinds of knowledge, in particular, between scientific and nonscientific forms of truth. The one kind of knowledge - what counts as true knowledge - is on the one side, while on the other side, there is no real knowledge; the 'other side' is relegated to the status of mere 'beliefs, opinions, intuitive or subjective understandings' that in the best cases would be issues for scientific inquiry. So, the 'abyssal thinking' consists of several distinctions/dichotomies 
that make up a divided world, a world of two separate realms: the realm of "this side" and the realm of "the other line" (SANTOS, 2007, p. 45).

Maybe the most important dimension of abyssal thinking is 'the impossibility of the copresence of the two sides of the line'. Through this kind construction, it is supposed that people stay in a static situation. But as López (2019) notes: although people of the one-side share elements, they are also different; and 'kinds of people are cemented through research and administrative apparati, but also through uprising and revolt' (p. 164). People are constructed in these kinds of ways for governmentality's purposes, but at the same time, since people are not just the object of static nominalism (HACKING, 2006), and not 'passive receivers of imperial administration and control', they react in resistant ways. Lopez (2019) identifies in this construction process that it is at once a fluid situation for both classifiers and classified and at the same time she comments that all of this a matter of control.

This kind of classification — for example, making up the otherness indigenous groups is strongly connected to the processes of colonization and racialization while simultaneously creating the alibi for oppressing them: it 'justified the violence of extermination, land grabs and reeducation practices and institutions' (BENSON, 2019). Interesting examples of the creation of this dichotomized world are found in the framework of Latin America; as a result of the globalized world in which western civilization expresses the coloniality of power and classifies the population using the idea of races, etc. Quijano presents the coloniality of power (QUIJANO, 2000) to challenge the way such lines are drawn, both literally by the drawing of land borders, and metaphorically by conceptions of the centre and the periphery.

López (2017) describes for example how official support for indigenous languages and cultures in the school curriculum of Guatemala perpetuates people who are now classified as indigenous as the resource for the modern economy, needing to perform better in schools and later to enter the workforce in ways that enable the nation state to compete in the global economy; what appears on the surface to be a celebration of indigenous culture is nevertheless the maintenance of coloniality.

How dominant western thinking has exercised power by creating hierarchies and dichotomies is typically reflected in Said's classical work, Orientalism (1978/2003). He mentioned in the introduction of his book that the framework of knowledge and power that creates the 'Oriental' [the different from the West, in essence] and in a way eliminates this person as now defined, is not an exclusively academic problem. Exploring his political interests in describing and analyzing the universal problem of Orientalism, its birth, development and establishment, he analyzed how 
orientalism is in fact an attempt to entangle the East and its representations to this particular knowledge system - an expression of the colonial power over the colonized people.

Said developed a discourse that composes his hybrid identity: as an Arab (by origin) as an American (due to the connection with the Western Academic Community), while drawing on the ideas of a series of Western scholars such as Foucault e.g., the duality of knowledge / power) and Gramsci (concept of hegemony) (GHAZI, 1998). Said's work criticizes Orientalism, exposing its failures and drawing on post-colonial perceptions, while emphasizes hybridity and points out that cultures are not separate, homogeneous. At the same time, this work emphasizes how the terms "East" or "West" appear to be ontologically stable, despite both being imagined constructions human effort products - and as such being objects of manipulation. Similar perspectives have kept practices that originate outside of the West outside the body of so-called academic knowledge.

Lopez Lopez's more recent paper (2019, p. 165) extends previous work on colonialism and coloniality. She explores the elements that are involved in constructing' categories of people (for example, indigeneity)": (a) Classifications are generated by coloniality. For example, "Indigenous," "Ladino" or "Non-Indigenous," and "Roma" are some of the classifications. (b) People are classified, usually people characterized by a certain risk factor that is considered to be an indication that they need help. The people to be classified are key in the emergence of (c) expert institutions (Universities, UNESCO etc.) that take on the tasks and have the authority to decide how to apply the classifications. (d) Expert knowledges are produced in combination by the above elements, and have the authority to make up the classifications. (e.) Experts have the knowledge, understand the classifications, work in the institutions, and make up one category of the kinds of people generated in this collection of element. School is one institution, of course; so are government ministries, social agencies, professional associations, religious and faith communities, and so on.

Lopez provides her experiences researching in Guatemala. She writes for example about an 'exercise' in a social science class that aimed to show the four types of people in Guatemala. India Maria's character was used as a stereotype that contributed to the further alienation and discrimination of the natives. Students are meant to learn about an anthropologist who is represented in positive terms as 'solving the Indian problem' by categorizing them in relation to their psychology, emotions, behavior. In Lopez Lopez's analysis, the combinations of classifications of people, people themselves, institutions, knowledges, and experts has over time been attempting to make the 'indigenous' Guatemalans a part of western culture, and in turn, as subjects of governmentality! We note that mathematics is hardly far away from social studies in this endeavor. Classifications are an essential mode of mathematization. 
In order to make clear the otherness construction and the fact that indigeneity (as well coloniality) is a matter of power, Lopez introduces (2017, p. 68) the various population registration and the way indigenous people are further categorized. For example, in the beginning of the $20^{\text {th }}$ Century, the emphasis was on style of clothing and skin color, while later it was on the place they had been born. At the end of 1994, the Mayan category appeared, and one could only answer if he identified himself as such. The character of Indian Maria (for a theatre performance) discusses her choice to deny such subjectivity. She refuses to be constructed in a way to be controlled.

Taking the opportunity from Maria's performance, the author wonders if we can refuse the tendency of education to manage young people in the light of bridging the gap, pluralism, inclusion and development. What are the dynamic ways in which people made up to be fixed are refusing in educational policies, in school leadership, in schools, in classrooms, in subjects, in lessons, in the playground, in daily conversations. What are that mechanisms to tame and contain their refusal? How am I implicated in that process? What can I as a researcher, scholar, or educator invent to meet the need to refuse? How can I refuse?

\section{Challenging the consequences of coloniality and indigeneity: Ending with Some Questions}

Inspired by our interest in ethnomathematics, and keeping the main agenda of challenging western epistemologies and dominance, we tried to change the narration. Questioning the ideas of indigeneity and coloniality, we explored their constructions and implications, and then we put in the center the need of challenging the abyssal thinking, and the associated line that creates a dichotomized world.

We used some examples from novels, considering them as allegories and the same time as a kind of isomorphism of what happens in a mathematics classroom when a Roma student or any other child that is from the other side of the line is asked to be adapted in a particular curriculum to experience hard acculturation process regarding cultural or cognitive issues In a framework where his personality is annihilated and he/she has to face very complicated situations.

Can one enjoy the privileges of western civilization (and academic/school knowledge) and yet perceive resistance in this acculturation process as a positive action of affirmation? What are the corresponding costs for any choice? What about students - mostly out of mainstream - at school that very often are confronting a similar dilemma? 
The character of Indian Maria enables one version of refusal as curriculum: In articulating the specific ways in which she refuses to be classified, into a type of person, by experts, within and by specific institutions, and according to theories and knowledge structures, she also takes command of those knowledges, schools herself in the expertise of coloniality in order to refuse it. But she goes further than refusing colonial structures.

She performs her own sense of self, declaring who and what she makes of her own world. She is multi-cultural and creole in the most complex sense of these words. We suggest a similar reappropriation of (Western) mathematics in and out of school as a parallel refusal of simple coloniality, in favor of a creolization that celebrates the ways in which local knowledges exploit the school mathematics as contributions that can be helpful in accomplishing local interests.

Similar to the government agencies who generate new curricula in Lopez Lopez' tales of Guatemala is the interest in Native Americans that was generated during the Obama administration in the United States. It was projected that the United States would need to add an additional 1 million college graduates in STEM fields per year for the next ten years to keep up with projected growth in science and technology expertise. At the same time, though, Native Americans and other indigenous groups were underrepresented in the sciences, making up only $0.2 \%$ of the STEM workforce in 2014 , despite being $2 \%$ of the total population of the United States. One question that arose was, 'Why are indigenous people still underrepresented in science?'

In this way, Native American Indians became a problem to be solved. Scientist and anthropologist Kim TallBear, an expert of her own on the historical role of science and observation in indigenous communities, notes how Western scientific culture can leave out other voices. She asks, 'What does an inclusive scientific enterprise look like, and how could we get there?' not to solve the STEM problem, but to help Native American Indian scientists go to universities and study science, in order to do the science they do - differently from Western science. That is, she is committed to helping members of her community to study the natural and physical world in ways that take advantage of the science in the universities, grounding what they do in the traditions and legacies of their own communities (TALLBEAR, 2019a, 2019b)

How are children enculturated/acculturated into such an approach to mathematics/ethnomathematics? One way is to help them to solve problems that they themselves have in life, using what they know, and helping them to find tools and concepts that can support such efforts. Instead of lessons that teach them basic mathematics, or instead of activities that celebrate local 'indigenous' mathematical practices, we encourage the use of local experts in the solution of child-generated problems. In particular, it can be exciting to imagine a curriculum where 
the children 'refuse' to be classified by the school or other social institutions that enact 'knowledges', instead exploiting the policies and classifications to serve their own purposes, a kind of poaching so-to-speak of coloniality.

We are happy closing with the reference of an interesting curricular experience that was provided by our Ph.D. student Giorgos Kyrakopoulos (2019, p. 178) at the most recent CIEAEM conference. He drew from a particular problem that Roma children face trying to cross a stream on the way to school when it is raining, and he managed to make them really involved in the design of solutions to this problem. Together, they developed interesting mathematical ideas - both of their own and those the teacher knew were included in the official school syllabus.

It is possible furthermore to describe the children's experiences with finding a solution to the crossing the stream in each of the six universal mathematical activities posited by Alan Bishop (1988). He did this because he knew enough about his students' lives and his students believed he was interested in their lives: they shared the difficulty in walking to school, how much further it was to walk to school in the rain, and how much this was making it less attractive to even come to school.

Exploring alternatives, measuring distances, and designing a footbridge actually made walking to school something they were invested in while also giving them the control over what and how to learn mathematics! It may seem odd to toss out this kind of an example at the end of our article, rather than to draw conclusions from a set of data. However, we see it as perhaps exemplary of a new form of working in ethnomathematics: our work here is not empirical, and instead guides empirical and policy projects, based on the philosophical and theoretical work we have proposed as useful, avoiding methodologies that re-inscribe coloniality.

\section{References}

ACHEBE, Chinua. Things fall apart. New York: Heinemann, 1958.

AHMED, Sara. Orientations: toward a queer phenomenology. GLQ: A journal of Lesbian and Gay Studies, v. 12, n. 4, p. 543-574, oct. 2006.

BENSON, Alan. Culturally Responsive Pedagogy: working towards decolonization, indigeneity and interculturalism (Review). London Review of Education, v. 17, n, 2, p. 236-238, jul. 2019.

BISHOP, Alan. Mathematical Enculturation: a cultural perspective on Mathematics Education. Dordrecht: D. Reidel Publishing Company, 1988.

CARDOSO, Dulce Maria. The Return. Translated by Ángel Gurría-Quintana. London : Quercus Books, 2016. 
CÉSAIRE, Aimé. Discourse on Colonialism. Translated by Joan Pinkham. New York and London: Monthly Review Press, 1972.

FANON, Franz. Black skin, white masks. New York: Grove Press, 1967.

FANON, Franz. Wretched of the Earth. New York: Grove Press, 1961.

FARAH, Nuruddin. North of Dawn: a novel. London: Penguin, 2018.

GERDES, Paulus. Ethnomathematics as a new research field, illustrated by studies of mathematical ideas in African history. In: KJELDSEN, Tinne Hoff; PEDERSEN, Stig Andur; SONNE-HANSEN, Lise Mariane. (Ed.). New trends in the History and Philosophy of Mathematics. Odence: University Press of Southern Denmark, 2004, p. 135-161.

GERDES, Paulus. Reflections on ethnomathematics. For the Learning of Mathematics, $v, 14, \mathrm{n}, 2$ : p. 19-22, jun. 1994.

GHAZI, Syed A. V.S. Naipaul, postcolonial orientalism and Islam. Toledo: University of Toledo, 1998.

HACKING, lan. Kinds of people: moving targets. London: The British Academy, 2006.

KHAN, Steven K. Ethnomathematics as mythopoetic curriculum. For the Learning of Mathematics, v. 31 , n. 3, p. 14-18, nov. 2011.

KYRIAKOPOULOS, Giorgos, Exploiting the six mathematical activities for responding to a real community's problem with young Roma children. INTERNATIONAL COMMISSION FOR THE STUDY AND IMPROVEMENT OF MATHEMATICS EDUCATION, 2019, Braga. Proceedings CIEAEM 71: Connections and understanding in mathematics education: Making sense of a complex world. Braga: Universidade do Minho, 2019.

LAHIRI, Jhumpa. The namesake: a novel. Boston: Houghton-Mifflin, 2004.

LÓPEZ, Ligia López. Refusing making. Journal of Curriculum and Pedagogy, v. 16, n. 2, p. 161174, 2019.

LÓPEZ, Ligia López. The making of indigeneity, curriculum history, and the limits of diversity. New York: Routledge, 2017.

LORDE, Audre. Sister outsider. essays and speeches. New York: Crossing Press, 1984.

QUIJANO, Aníbal. Coloniality of power and Eurocentrism in Latin America. International Sociolog, v. 15, n, 2, p. 215-232, 2000.

SANTOS, Boaventura de Sousa. Between Prospero and Caliban: colonialism, postcolonialism, and inter-identity. Luso-Brazilian Review, v. 39, n. 2, p. 9-43, 2002.

SANTOS, Boaventura de Sousa. Beyond abyssal thinking: from global lines to ecologies of knowledges. Review, v. 30, n. 1, p. 45-89, 2007.

STATHOPOULOU, Charoula. Ethnomathematics: exploring the cultural dimension of Mathematics and of Mathematics Education. Athens: Atrapos, 2005. 
STATHOPOULOU, Charoula. Once Upon a Time... The Gypsy Boy Turned 15 While Still in the First Grade. In: ROSA, Milton; SHIRLEY, Lawrence; GAVARRETE, Maria Elena; ALANGUI, Wilfredo V. (Ed.), Ethnomathematics and its diverse approaches for Mathematics Education. Cham, Switzerland: Springer, 2017, p. 97-123.

TALLBEAR, Kim. Widening the lens on a more inclusive science. Science Friday, v. 9, n. 6, 2019b. NPR (National Public Radio).

TALLBEAR, Kim. Caretaking relations, not American dreaming. Kalfou: a Journal of Comparative and Relational Ethnic Studies, v. 16, n. 1, p. 24-41, 2019a.

TUCK, Eve; YANG, Wayne. R-words: Refusing research. In: PARIS, Django; WINN, Maisha T. (Ed.). Humanizing research: decolonizing qualitative inquiry with youth and communities. Washington: SAGE Publications, 2014, p. 223-248. 